\title{
MEAT SUPPLY CHAIN IN THE PERSPECTIVE OF UN SDGS
}

Received 18.08.2021

Accepted in revised 06.09.2021 Accepted for publication 15.09.2021

\author{
Ilija V. Djekic \\ University of Belgrade, Faculty of Agriculture, Belgrade, Serbia
}

\begin{abstract}
Keywords: meat and meat products, supply chain, United Nations, sustainability development goals
\section{Abstract}

This paper presents an overview of the meat supply chain in the perspective of main UN sustainable development goals (SDGs). To perform this overview, meat supply chain was presented with five main stakeholders (livestock farmers, slaughterhouses, meat processors, retailers and consumers). As this chain is specific, four SDGs have been revealed as most important, as follows: SDG6 Clean water and sanitation; SDG7 - Affordable and clean energy; SDG12 - Sustainable consumption and production; SDG13 Climate action. Discussion and literature review was performed for each of the four UN SDGs. In addition, other UN SDGs of interest for this supply chain have been briefly presented.
\end{abstract}

\section{Introduction}

The Sustainable Development Goals (SDGs) comprise of 17 goals deployed into 169 targets and 232 indicators that aim to strive the World to a more sustainable future. They were defined by the United Nations General Assembly in 2015 by leaders of almost 200 countries [1]. Although generic, food systems have been identified as one of key sectors that need to be tackled in order to achieve the UN SDGs by 2030. During July 2021, a Food Systems pre-summit was held in Rome where participants from all around the world discussed how to improve national pathways and address different impacts of food systems associated with UN SDGs "based on the best science and reflecting local and national realities within a global context" [2]. In September 2021, the UN Secretary-General António Guterres will assemble the Food Systems Summit. It is expected that the Summit will initiate a variety of actions related to all 17 SDGs, focused on healthier, more sustainable, and equitable food systems [3]. The Food and Agriculture Organization (FAO) of the United Nations has identified eight (out of 17) UN SDGs that are directly associated with food systems, as follows: SDG1 - No Poverty; SDG2 - Zero Hunger; SDG6 - Clean water and sanitation; SDG7 - Affordable and clean energy; SDG12 - Sustainable consumption and production; SDG13 - Climate action; SDG14 Life below water and SDG15 - Life on land [4]. Other nine UN SDGs are indirectly related to food systems.

When it comes to meat and meat supply chains, many studies identify this sector as one of main environmental polluters in the food system [5]. The livestock sector's has severe environmental emissions on air, water and soil, joint with needs for natural resources such as water and energy [6]. Meat slaughtering and processing additionally put pressure on the environment from emissions into the environment and/or from the consumption of all kinds of natural resources [7]. To summarize, all environmental impacts of this chain influence three dimensions: (i) cli- mate change in respect to the global warming potential; (ii) consumption of natural resources and (iii) pollution of the environment caused by waste water discharge and waste disposal [8]. In parallel, global consumption of meat has increasing in terms of its overall production and consumption as a result of growing world's population and consumption of meat per capita [9]. In relation to its sustainability pillars, meat production and consumption directly affect the economy, the society and the environment [10]. To better understand the meat supply chain, one of approaches is to present it from a "farm to fork" perspective [11]. In that sense, this chain consists of five main links: (i) livestock farms (ii) slaughterhouses (iii) meat processing plants (iv) customers / retail and (v) meat consumers / households [8].

The objective of this paper is to analyze meat supply chains from the perspective of four UN Sustainable development goals, as follows: SDG6 - Clean water and sanitation; SDG7 - Affordable and clean energy; SDG12 - Sustainable consumption and production; SDG13 - Climate action. In addition, a short discussion regarding other UN SDGs has been provided.

\section{Objects and methods}

To perform an overview on connecting UN SDGs and the meat supply chain, at first glance it was obvious that a literature review with combinations of various key words (meat production / meat supply chain vs specific UN SDGs) in various scientific databases will raise different results. Since this topic is dispersed through different types of scientific publications (research and review articles, book chapters, conference papers, editorials, etc.), main focus was to identify four key UN SDGs clearly connected with the meat supply chain. Therefore, the focus of this overview was to shed light on SDGs no.6, no.7, no.12 and no.13 and their connection with the meat supply chain. 


\section{Results and discussion}

SDG6 - Clean water and sanitation and the meat supply chain

The need for clean, accessible water is one of the UN SDGs since the world is striving for sufficient fresh water opposed to water scarcity, poor water quality and inadequate sanitation that has a negative severe impact on food security throughout any food supply chain [12]. The meat industry requires adequate supply of potable water for both meat processing and hygiene and sanitation to ensure meat and meat products are not contaminated. Therefore, one of key targets associated with meat and meat products is how to produce more using less water [4].

Meat slaughtering and meat processing are the two links in the meat supply chain that require potable water while they also discharge significant volumes of pollutant wastewater [13]. However, the entire chain is a big user as water is important for live animals at farms and when entering the slaughterhouse as well as for hygiene and sanitation of slaughterhouses, meat processing plants and retail, and finally for use at households for meat preparation $[8,14]$.

Water used in the meat supply chain comes from different sources, such as ground or surface water and is extensively used for numerous technological purposes in different quantities satisfying requirements outlined in water safety and quality standards [15]. Also, in some meat processing products it is a primary ingredient like in the case of hams and sausages. In these cases, water needs to be of highest "potable" quality. When used for non-processing purposes such as boiler feed water, fire-extinguishing water, pasteurizing, heating or cooling medium, quality of such water is medium to high [16]. As wastewater from meat industry may be a big environmental polluter, it is important to protect all water sources and treat wastewater with similar care [15].

\section{SDG7 - Affordable and clean energy and the meat supply chain}

Different types of energy are used throughout the meat supply chain basically for machines and equipment, for controlling temperature regimes (heating / refrigerating) and for transportation purposes [14, 17]. Its source is deployed in terms of clarifying consumption from electric energy, thermal energy and other sources of energy, such as types and quantities of fossil fuels.

Advanced housekeeping practices in the meat sector can obtain improvements while additional savings can be made through promoting energy efficiency associated with equipment and heat recovery systems $[18,19]$. A promising approach in reducing energy consumption and related energy costs is through energy management [20]. Some types of organic solid waste classified as biomass can facilitate energy recovery instead of their disposal [21]. Biomass to energy conversion are routes to energetic and economic benefits $[21,22]$. Recovering methane from manure is an- other potential of energy improvements in the meat sector [19]. This type of waste can also be used as a secondary fuel for thermal energy [23]. The main goal of thermal disposal of (organic) wastes is its conversion to safe materials, as well as in reducing its weight and volume [24].

SDG12 - Sustainable consumption and production and the meat supply chain

From 1961 to 2011, global meat consumption almost doubled from $23.1 \mathrm{~kg}$ per capita per annum to $42.2 \mathrm{~kg}$ per capita per annum [25]. Regarding expected population growth, total consumption will increase yearly by almost $1.5 \%$ [26]. Major contributor to global meat production originates in the pig sector while the poultry sector is the fastest growing livestock sector as it's a source of healthy high protein and low-fat type of meat [27-29]. Consumption of animal-based proteins has increased during a halfcentury period worldwide (1961-2011), from $61 \mathrm{~g}$ per capita per day up to $80 \mathrm{~g}$ per capita per day [25].

However, not only from a nutritional point of view, consumption of meat is also studied in terms of its environmental impact [30]. The FAO has coined a new term "sustainable diet" associated to diets with optimal healthy and low environmental impacts [31]. As a result, some authors claim that main trigger in "sustainable diets" is to avoid meat and meat products due to their severe environmental impacts. However, global warming potential of meat consumption compared to other products is not so much higher as one would assume analyzing some media and literature. Also, most authors associate climatic impact of food with both production and consumption [30], with limited number of papers that analyzed impact of meat consumption [32]. Finally, in line with various dietary habits that exclude consumption of meat and meat products such as veganism, vegetarianism, raw foodism, or fruitarianism, still a large majority of people eat meat regularly or occasionally [33]. Such environmental pressure on changing dietary habits is still more a scientific que than an every-day routine. One of a few studies that analyzed replacement of animal origin food with plant-based substitutes revealed some potentials in changing dietary habits in parallel with decreasing environmental impacts [34].

SDG13 - Climate action and the meat supply chain

Speaking about climate action (SDG13), agriculture is one of sector that will play a big role in responding to climate change [4]. Based on the Paris Agreement [35], two main actions arise: (i) limiting the global warming to below $2{ }^{\circ} \mathrm{C}$ above pre-industrial levels and to pursue efforts in limiting the increase of temperature to $1.5^{\circ} \mathrm{C}$ [36] and (ii) preventing these threats to food systems [37]. Main challenge is how to produce sufficient amounts of food for the world's population from the perspective of observing interaction between climate change and food production. The impact of meat production is twofold in terms that meat production has an impact on climate change and vice versa, climate change has an impact on meat production [38]. 
Analysis of meat on climate change can be observed from life-cycle assessment studies, such as analysis of pork, beef and chicken meat production [33]. These studies confirm that carbon footprint (expressed as carbon-dioxide equivalent $-\mathrm{CO}_{2 \mathrm{e}}$ ) is the main predictor of evaluating climate change impact of the meat supply chains [39]. For calculating $\mathrm{CO}_{2 \mathrm{e}}$, it is necessary to measure all greenhouse gasses emissions [40]. In parallel, ozone depletion potential expressed as CFC-11 or R11 equivalents is an additional indicator used to measure the potential for reducing the protective stratospheric ozone layer [41]. This indicator indirectly affects climate change and is associated with maintaining cold chains and using refrigerants for chilling / freezing [42]. These cold chains are vital for keeping meat safe since inadequate temperatures inhibit growth of harmful microorganisms [43].

Households are responsible for preparing meat but also for discarding meat waste [44]. Reasons for discarding meat waste are expired date and rotten taste and/or smell [45]. In order to maintain meat safety, control of the cold chain joint with expiring date care are very important [38] as consumers are the weakest link in cold chains.

Temperature increase joint with climate variability affect quality of feed [46] causing an increase of mycotoxins in crops used for feed [47]. As an example, maize represents a typical crop used in feed production where presence of fumonisins is directly correlated with chronic exposure [48]. Second threat observed at farm levels are animal diseases caused by temperature rise such as death of animal further causing growth of pathogens, parasites and various vector-borne diseases [46].

Heat stress causes additional water needs for animals. Their response are dietary changes (less feed / more water) and changes in reproductive and productive effectiveness [49]. These changes lead to energy disbalances and reduction of animal weight [50] causing decrease of meat production by growth and carcass weight [49], economic losses [51]. Finally, reproduction efficiency during heat stress affects animal fertility [52], embryo development and pregnancy rate [53]. It is assumed that temperature rise may cause up to $30 \%$ of biodiversity loss of both plants and animals [54]. Depending on the region, highest risks linked with livestock and breed elimination are with chicken, followed by pigs and cattle [46].

\section{Indicators associated with UNSDGs}

To calculate impacts associated with selected UN SDGs, it is common to introduce and calculate environmental performance indicators (EPIs) defined as a "measurable representation of the status of operations, management or conditions related to environmental aspects" [55]. To evaluate meat production, it is important to define a functional unit (FU) in which the impacts are presented and to define formula as this is the basis for all further comparisons [11]. In the meat supply chain, the most common FUs are one $\mathrm{kg}$ of livestock [56, 57], one $\mathrm{kg}$ of carcass $[58,59]$ and one $\mathrm{kg}$ of meat / meat products [60].
In every meat supply chain, it is common to calculate consumptions and discharges per meat FUs such as water consumption per FU and wastewater discharge per FU directly associated with SDG6 $[14,19,42]$ or energy-to-meat ratio, associated with SDG7. As presented above, global warming potential is recognized as an environmental indicator associated with the meat chain [39], linked with SDG13. The GWP is calculated for each link of the meat supply chain.

Table 1 depicts main indicators associated with four SDGs and the meat supply chain $[15,33]$.

Considering the link of the four UN SGDs and the meat supply chain, Figure 1 depicts the most influential UN SDGs in terms of its severity and time-scale associated with all five links in the meat chain. The most severe and long lasting stage is at farms with SDG13 as the most influential. Slaughtering and meat processing are activities that lasts short (related to one FU) but the overall impact of slaughtering and meat processing on water consumption and wastewater discharge is high (SDG6). Within retails, meat can be stored for a long period of time, but the impact is not so high, mainly associated with energy consumption for maintaining the cold chain (SDG7). Finally, lowest impact is associated with meat consumers / households where meat is often consumed within 7 days from purchasing. This activity is mostly associated with SDG12.

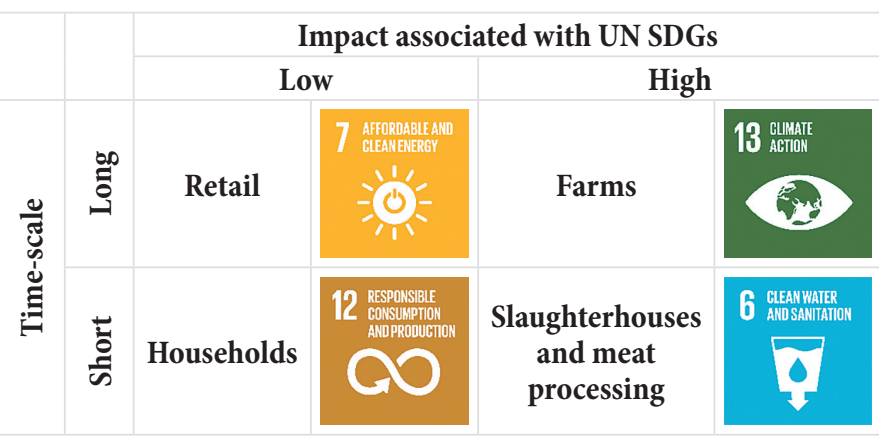

Figure 1. Four UN SDGs and their impacts on the five links in the meat supply chain

Other UN SDGs and the meat supply chain

Adapting to climate change for small - scale livestock farms is needed to enhance food security (SDG2 - Zero Hunger) and reduce poverty (SDG1 - No Poverty) of all types of small farmers $[61,62]$. This is pronounced since 80 percent of extremely poor people live in rural areas depending on various aspects of agriculture - farming, fisheries and forestry [4]. Improvement of food (meat) trade is in direct correlation with making accessible and affordable safe and healthy meat (SDG2 - Zero Hunger; SDG3 Good health and well-being). Considering that three billion people receive 20 percent of their daily animal protein intake from fish, it is obvious that sustainable management of oceans, seas and marine resources in important for the fish supply chain, namely sustainable fisheries [4]. Modernization of meat processing can indirectly impact this 
Table 1. Indicators associated with four SDGs and the meat supply chain

\begin{tabular}{|c|c|c|}
\hline UN SDG & Indicator & Formula [unit] \\
\hline & \multirow{6}{*}{ Consumption of water per FU } & Consumption of water $[L]$ \\
\hline & & FU [kg of livestock] \\
\hline & & Consumption of water $[L]$ \\
\hline & & $F U[$ kg of carcass $]$ \\
\hline & & Consumption of water $[L]$ \\
\hline & & $F U[k g$ of meat product $]$ \\
\hline & \multirow{2}{*}{ Reuse of water [\%] } & Water reuse $[L]$ \\
\hline & & Water reuse $[L]+$ Water consumption $[L]$ \\
\hline \multirow[t]{10}{*}{ 6. GIEANWAIER } & Water quality index (WQI) & $\begin{array}{l}\text { Ranking the WQI from 1-100 (depending on the legislation / methodology applied } \\
\text { and parameters measured). The 'rule of the thumb' is 'the higher the WQI, value, the } \\
\text { better the quality' of water. }\end{array}$ \\
\hline & \multirow{6}{*}{ Discharge of wastewater per FU } & Discharge of wastewater $[L]$ \\
\hline & & FU $[$ kg of livestock $]$ \\
\hline & & Discharge of wastewater $[L]$ \\
\hline & & $F U[k g$ of carcass $]$ \\
\hline & & Discharge of wastewater $[L]$ \\
\hline & & $F U[k g$ of meat product $]$ \\
\hline & Wastewater quality index (WWQI) & $\begin{array}{l}\text { Ranking the WWQI from 1-100 (depending on the legislation / methodology } \\
\text { applied and parameters measured). The 'rule of the thumb' is 'the higher the WWQI } \\
\text { value, the higher the quality of wastewater'. }\end{array}$ \\
\hline & \multirow{2}{*}{ Water efficiency [\%] } & Water consumption $[L]=100$ \\
\hline & & Wastewater discharge $[L]$ \\
\hline \multirow{6}{*}{$\begin{array}{l}7 \text { AFFORDABIEAND } \\
\text { GLEANENERGY }\end{array}$} & \multirow{6}{*}{ Consumption of energy per FU } & Consumption of energy $[M J]$ \\
\hline & & $F U[k g$ of livestock $]$ \\
\hline & & Consumption of energy $[M J]$ \\
\hline & & $F U[$ kg of carcass $]$ \\
\hline & & Consumption of energy $[M J]$ \\
\hline & & $F U[k g$ of meat product $]$ \\
\hline 18 GUMATE & Global warming potential & $\begin{array}{c}G W P=\sum_{i}^{\mathrm{n}} G W P_{i} x m_{i}\left[\mathrm{kgCO}_{2 e}\right] \\
m_{i}-\text { mass of emitted gas }(\mathrm{kg}) ; G W P_{i}-\text { global warming potential of the emitted gas. }\end{array}$ \\
\hline $\begin{array}{l}12 \text { RESPONSBIE } \\
\text { EONSULPTION } \\
\text { ANDPRODUETION }\end{array}$ & \multicolumn{2}{|r|}{ ALL OF THE ABOVE } \\
\hline
\end{tabular}

Legend: FU - Functional unit (livestock, carcass, meat / meat product); GWP - Global warming potential

supply chain, with more use of digital technologies, optimization and innovation of processing, including Food Industry 4.0 supported by efficient infrastructures [63]. This may be connected with SDG9 - Industry, motivation and infrastructure.

Finally, all stakeholders connected with the meat supply chain (legal authorities, inspection services, academia) should act as partners in improving this chain aligning to the motivation of achieving SDG 17 - Partnerships for the goals. A good example is the technical commit- tee ISO/TC34 'Food products' [64] declaring that they contribute to the following SDGs (SDG1 - No Poverty, SDG2 - Zero Hunger, SDG3 - Good health and wellbeing, SDG5 - Gender equality, SDG8 - Decent work and economic growth, SDG10 - Reduced inequalities, SDG11 - Sustainable cities and communities, SDG12 Responsible consumption and production, SDG13 - Climate action, SDG15 - Life on land and SDG16 - Peace, justice and strong institutions) with published food related standards. 


\section{Conclusion}

Considering meat customers (retail / consumers), meat producers (farms / slaughterhouses / processors) and UN SDGs as cornerstones of an interactive triangle, the area within elevates a perspective of improvement opportunities in terms of sustainable production and consumption associated with SDG12. It is expected that this will pave the way in supporting sustainable technologies as well as sustainable diets promoting both sus- tainable and nutritional values associated with all types of meat and meat products and leaving the (meat) consumers with a free choice. In parallel, striving towards SDG17 - Partnerships for the goals enables deeper fulfillment of all UN SDGs and all stakeholders in the meat supply chain continuum. It is obvious that further attempts are needed to pave the way for fulfilling the UN SDGs' targets and exceeding expectation of all meat supply chain stakeholders.

\section{REFERENCES}

1. UN. (2016). Transforming our world: The 2030 agenda for sustainable development. United Nations: New York, USA.

2. UN. (2021). More than 100 countries discuss visions for national food futures to accelerate global action ahead of September Summit. Food Systems Summit 2021. Retrieved from https://www.un.org/en/food-systems-summit/news/more-100countries-discuss-visions-national-food-futures-accelerate-global. Accessed June 19, 2021

3. UN. (2021). About the Summit. Food Systems Summit 2021. Retrieved from http://unstats.un.org/unsd/methods/m49/ m49regin.htm. Accessed June 25, 2021

4. FAO. (2015). FAO and the 17 Sustainable Development Goals. Food and Agriculture Organization of the United Nations and World Health Organization Rome, Italy.

5. Röös, E., Sundberg, C., Tidåker, P., Strid, I., Hansson, P.-A. (2013). Can carbon footprint serve as an indicator of the environmental impact of meat production? Ecological Indicators, 24 , 573-581. https://doi.org/10.1016/j.ecolind.2012.08.004

6. de Vries, M. de Boer, I.J.M. (2010). Comparing environmental impacts for livestock products: A review of life cycle assessments. Livestock Science, 128(1-3), 1-11. https://doi.org/10.1016/j. livsci.2009.11.007

7. Lopez-Ridaura, S., Werf, H., Paillat, J.M., Le Bris, B. (2009). Environmental evaluation of transfer and treatment of excess pig slurry by life cycle assessment. Journal of Environmental Management, 90(2), 1296-1304. https://doi.org/10.1016/j.jenvman.2008.07.008

8. Djekic, I., Tomasevic, I. (2016). Environmental impacts of the meat chain - Current status and future perspectives. Trends in Food Science and Technology, 54, 94-102. http://doi. org/10.1016/j.tifs.2016.06.001

9. Henchion, M., McCarthy, M., Resconi, V.C., Troy, D. (2014). Meat consumption: Trends and quality matters. Meat science, 98(3), 561-568. http://doi.org/10.1016/j.meatsci.2014.06.007 10. Allievi, F., Vinnari, M., Luukkanen, J. (2015). Meat consumption and production - analysis of efficiency, sufficiency and consistency of global trends. Journal of Cleaner Production, 92, 142151. http://doi.org/10.1016/j.jclepro.2014.12.075

11. Djekic, I., Sanjuán, N., Clemente, G., Jambrak, A.R., DjukićVuković, A., Brodnjak, U.V. et al. (2018). Review on environmental models in the food chain - Current status and future perspectives. Journal of Cleaner Production, 176, 1012-1025. https://doi.org/10.1016/j.jclepro.2017.11.241

12. UNESCO. (2017). Education for Sustainable Development Goals: Learning Objectives. United Nations Educational, Scientific and Cultural Organization,: Paris, France.

13. Meneses, Y.E., Stratton, J., Flores, R.A. (2017). Water reconditioning and reuse in the food processing industry: Current situation and challenges. Trends in Food Science and Technology, 61, 72-79. https://doi.org/10.1016/j.tifs.2016.12.008

14. IPPC. (2006). Integrated Pollution Prevention and Control, in Reference Document on Best Available Techniques in the Food, Drink and Milk Industries. European Commission: Seville, Spain. 15. Djekic, I., Tomasevic, I. (2020). Role of Potable Water in Food Processing, in Clean Water and Sanitation, W. Leal Filho, et al., Editors., Springer International Publishing: Cham. p. 1-10.

16. Kirby, R.M., Bartram, J., Carr, R. (2003). Water in food production and processing: quantity and quality concerns. Food Control, 14(5), 283-299. https://doi.org/10.1016/S09567135(02)00090-7

17. Djekic, I. (2015). Environmental impact of meat industry current status and future perspectives. International 58th Meat Industry Conference "Meat Safety and Quality: Where it goes?". Belgrad, Serbia. http://doi.org/10.1016/j.profoo.2015.09.025
18. Djekic, I., Blagojevic, B., Antic, D., Cegar, S., Tomasevic, I. Smigic, N. (2016). Assessment of environmental practices in Serbian meat companies. Journal of Cleaner Productionm 112 2495-2504. http://doi.org/10.1016/j.jclepro.2015.10.126 19. UNEP. (2000). Cleaner Production Assessment in Meat Processing, D.e. p. a.-D.M.o. e. a. energy, Editor., United Nations Environment Programme Division of Technology, Industry and Economics: Paris, France.

20. Schulze, M., Nehler, H., Ottosson, M., Thollander, P. (2016) Energy management in industry - a systematic review of previous findings and an integrative conceptual framework. Journal of Cleaner Production, 112, 3692-3708. http://doi.org/10.1016/j. jclepro.2015.06.060

21. Virmond, E., Schacker, R.L., Albrecht, W., Althoff, C.A., de Souza, M., Moreira, R.F.P.M. et al. (2011). Organic solid waste originating from the meat processing industry as an alternative energy source. Energy, 36(6), 3897-3906. http://doi.org/10.1016/j. energy.2010.08.026

22. Zheng, G., Koziński, J.A. (2000). Thermal events occurring during the combustion of biomass residue. Fuel. 79(2), 181-192 http://doi.org/10.1016/S0016-2361(99)00130-1

23. Arvanitoyannis, I.S., Ladas, D. (2008). Meat waste treatment methods and potential uses. International Journal of Food Science and Technology, 43(3), 543-559. http://doi.org/10.1111/ j.1365-2621.2006.01492.x

24. Bujak, J.W. (2015). New insights into waste management Meat industry. Renewable Energy, 83, 1174-1186. http://doi. org/10.1016/j.renene.2015.06.007

25. Sans, P., Combris, P. (2015). World meat consumption patterns: An overview of the last fifty years (1961-2011). Meat science, 109, 106-111. https://doi.org/10.1016/j.meatsci.2015.05.012

26. OECD/FAO (2017). OECD-FAO Agricultural Outlook 20172026 (Special focus South East Asia). OECD Publishing.

27. MacLeod, M., Gerber, P., Mottet, A., Tempio, G., Falcucci, A., Opio, C. et al. (2013). Greenhouse gas emissions from pig and chicken supply chains - A global life cycle assessment. Food and Agriculture Organization of the United Nations: Rome.

28. FAO. (2013). Poultry Development Review. Retrieved from http://www.fao.org/docrep/019/i3531e/i3531e.pdf Accessed January 19, 2018

29. OECD-FAO. (2016). OECD-FAO Agricultural Outlook 20162025. Retrieved from http://www.fao.org/3/a-i5778e.pdf Accessed January 19, 2018

30. Hyland, J.J., Henchion, M., McCarthy, M., McCarthy, S.N. (2017). The role of meat in strategies to achieve a sustainable diet lower in greenhouse gas emissions: A review. Meat science, 132, 189-195. https://doi.org/10.1016/j.meatsci.2017.04.014 31. Lang, T. (2012). Sustainable Diets and Biodiversity: The challenge for policy, evidence and behaviour. International Scientific Symposium, Biodiversity and Sustainable Diets United Against Hunger, FAO Headquarters, Rome, Italy, 3-5 November 2010. Book of Proceedings Sustainable Diets and Biodiversity: Directions and Solutions for Policy, Research and Action, 20-27. Food and Agriculture Organization of the United Nations.

32. Djekic, I., Bozickovic, I., Djordjevic, V., Smetana, S., Terjung, N., Ilic, J. et al. (2021). Can we associate environmental footprints with production and consumption using Monte Carlo simulation? Case study with pork meat. Journal of the Science of Food and Agriculture, 101(3), 960-969. https://doi. org/10.1002/jsfa.10704

33. Djekic, I., Tomasevic, I. (2018). Environmental Indicators in the Meat Chain. Chapter in a book: Quantification of Sustainability Indicators S. S. Muthu, Editor., Springer Singapore: Singapore. p. 55-82. https://doi.org/10.1007/978-981-13-2408-6_3 
34. Westhoek, H., Lesschen, J.P., Rood, T., Wagner, S., De Marco, A., Murphy-Bokern, D. et al. (2014). Food choices, health and environment: Effects of cutting Europe's meat and dairy intake. Global Environmental Change. 26(1), 196-205. https://doi. org/10.1016/j.gloenvcha.2014.02.004

35. UN. (2015). Paris Agreement, U.N.F.C.o.C.C. (UNFCCC), Editor., United Nations: Paris, France.

36. UN. (2015). Adoption of the Paris Agreement, in Report No. FCCC/CP/2015/L.9/Rev.1., F.C.o.C. Change, Editor., United Nations: Paris, France.

37. Doelman, J.C., Stehfest, E., Tabeau, A., van Meijl, H. (2019). Making the Paris agreement climate targets consistent with food security objectives. Global Food Security, 23, 93-103. https://doi.org/10.1016/j.gfs.2019.04.003

38. Djekic, I., Tomasevic, I. (2020). Impact of Animal Origin Food Production on Climate Change and Vice Versa: Analysis from a Meat and Dairy Products Perspective. Chapter in a book: Handbook of Climate Change Management: Research, Leadership, Transformation, W. Leal Filho, J. Luetz, and D. Ayal, Editors., Springer International Publishing: Cham. p. 1-16.

39. Dekić, I., Tomašević, I. (2017). Environmental footprints in the meat chain. Paper presented at the IOP Conference Series: Earth and Environmental Science, 85(1), Article 012015 https://doi. org $/ 10.1088 / 1755-1315 / 85 / 1 / 012015$

40. Herva, M., Franco, A., Carrasco, E.F., Roca, E. (2011). Review of corporate environmental indicators. Journal of Cleaner Production, 19(15), 1687-1699. https://doi.org/10.1016/j. jclepro.2011.05.019

41. Čuček, L., Klemeš, J.J., Kravanja, Z. (2015). Overview of environmental footprints. Chapter in a book: Assessing and Measuring Environmental Impact and Sustainability. Elsevier. p. 131193.

42. Djekic, I., Radović, Č., Lukić, M., Stanišić, N., Lilić, S. (2015). Environmental life-cycle assessment in production of pork products. Meso, XVII(5), 345-351.

43. Sofos, J.N. (2014). Meat and Meat Products. Capter in a book: Food Safety Management, Y. M. Lelieveld, Editor., Academic Press: San Diego. p. 119-162.

44. Visschers, V.H.M., Wickli, N., Siegrist, M. (2016). Sorting out food waste behaviour: A survey on the motivators and barriers of self-reported amounts of food waste in households. Journal of Environmental Psychology, 45, 66-78. https://doi.org/10.1016/j. jenvp.2015.11.007

45. Djekic, I., Miloradovic, Z., Djekic, S., Tomasevic, I. (2019). Household food waste in Serbia - Attitudes, quantities and global warming potential. Journal of Cleaner Production, 229, 44-52. https://doi.org/10.1016/j.jclepro.2019.04.400

46. Rojas-Downing, M.M., Nejadhashemi, A.P., Harrigan, T., Woznicki, S.A. (2017). Climate change and livestock: Impacts, adaptation, and mitigation. Climate Risk Management, 16, 145163. https://doi.org/10.1016/j.crm.2017.02.001

47. Wu, F., Bhatnagar, D., Bui-Klimke, T., Carbone, I., Hellmich, R., Munkvold, G. et al. (2011). Climate change impacts on mycotoxin risks in US maize. World Mycotoxin Journal, 4(1), 79-93. https://doi.org/10.3920/WMJ2010.1246

48. Udovicki, B., Djekic, I., Stankovic, S., Obradovic, A., Rajkovic, A. (2019). Impact of climatic conditions on fumonisins in maize grown in Serbia. World Mycotoxin Journal, 12(2), 183-190. https://doi.org/10.3920/WMJ2018.2364

49. Nardone, A., Ronchi, B., Lacetera, N., Ranieri, M.S., Bernabucci, U. (2010). Effects of climate changes on animal production and sustainability of livestock systems. Livestock Science, 130(1-3), 57-69. https://doi.org/10.1016/j.livsci.2010.02.011
50. Henry, B., Charmley, E., Eckard, R., Gaughan, J. B., Hegarty, R. (2012). Livestock production in a changing climate: Adaptation and mitigation research in australia. Crop and Pasture Science, 63(3), 191-202. https://doi.org/10.1071/CP11169

51. St-Pierre, N. R., Cobanov, B., Schnitkey, G. (2003). Economic losses from heat stress by US livestock industries1. Journal of Dairy Science, 86(SUPPL. 1), E52-E77. https://doi.org/10.3168/ jds.S0022-0302(03)74040-5

52. De Rensis, F. Scaramuzzi, R.J. (2003). Heat stress and seasonal effects on reproduction in the dairy cow - a review. Theriogenology, 60(6), 1139-1151. https://doi.org/10.1016/S0093$691 \times(03) 00126-2$

53. Hansen, P. (2007). Exploitation of genetic and physiological determinants of embryonic resistance to elevated temperature to improve embryonic survival in dairy cattle during heat stress. Theriogenology, 68, S242-S249. https://doi.org/10.1016/j.theriogenology.2007.04.008

54. IPCC. (2014). Climate Change 2014, Impacts, Adaptation, and Vulnerability, Part A: Global and Sectoral Aspects, Working Group II Contribution to the Fifth Assessment Report of the Intergovernmental Panel on Climate Change. Cambridge University Press Cambridge, UK.

55. ISO 14001:2015 "Environmental management systems Requirements with guidance for use". International Organization for Standardization: Geneva, Switzerland.

56. Dalgaard, R., Halberg, N., Hermansen, J.E. (2007). Danish pork production - An environmental assessment. DJF Animal Science, No.82. University of Aarhus - Faculty of Agricultural Sciences.

57. Basset-Mens, C., van der Werf, H.M.G. (2005). Scenariobased environmental assessment of farming systems: the case of pig production in France. Agriculture, Ecosystems and Environment, 105(1-2), 127-144. http://doi.org/10.1016/j. agee.2004.05.007

58. Williams, A.G., Audsley, E., Sandars, D.L. (2006). Determining the environmental burdens and resource use in the production of agricultural and horticultural commodities. In Main Report Defra Research Project IS0205. Bedford: Cranfield University and Defra.

59. Nguyen, T.L.T., Hermansen, J.E., Mogensen, L. (2011). Environmental Assessment of Danish Pork. Aarhus University, Aarhus, Denmark.

60. Cederberg, C., Flysjö, A. (2004). Environmental Assessment of Future Pig Farming Systems - Quantifications of Three Scenarios from the F00D21 Synthesis Work. The Swedish Institute for food and agriculture.

61. Ali, A., Erenstein, 0. (2017). Assessing farmer use of climate change adaptation practices and impacts on food security and poverty in Pakistan. Climate Risk Management, 16, 183-194. https://doi.org/10.1016/j.crm.2016.12.001

62. Khanal, U., Wilson, C., Rahman, S., Lee, B.L., Hoang, V.N. (2021). Smallholder farmers' adaptation to climate change and its potential contribution to UN's sustainable development goals of zero hunger and no poverty. Journal of Cleaner Production, 281, Article 124999. https://doi.org/10.1016/j. jclepro.2020.124999

63. Jambrak, A. R., Nutrizio, M., Djekić, I., Pleslić, S., Chemat, F. (2021). Internet of nonthermal food processing technologies (iontp): Food industry 4.0 and sustainability. Applied Sciences (Switzerland), 11(2), 1-20. https://doi.org/10.3390/ app11020686

64. ISO. (2021). ISO/TC34 Food products. Retrieved from https://www.iso.org/committee/47858.html. Accessed July 12, 2021.

\section{AUTHOR INFORMATION}

Ilija V. Djekic — PhD, full professor, full professor, Department for Food Safety and Quality Management, Faculty of Agriculture, University of Belgrade. 6 Nemanjina, Zemun, 11080, Belgrade, Serbia.E-mail: idjekic@agrif.bg.ac.rs

ORCID: https://orcid.org/0000-0002-8132-8299

The author bears responsibility for the work and presented data.

The author declares no conflict of interest. 